\title{
Investigation of the Efficacy of the Use of Cyanoacrylate in the Treatment of Venous Insufficiency: Single Center Short and Mid-Term Retrospective Results
}

\section{Venöz Yetmezlik Tedavisinde Siyanoakrilat Kullanımının Etkinliğinin İncelenmesi: Tek Merkez Kısa ve Orta Dönem Retrospektif Sonuçlarımız}

\author{
Mehmet Okan Donbaloğlu ${ }^{*}$ \\ ${ }^{1}$ Namık Kemal University, Faculty of Medicine, Tekirdağ, Türkiye. \\ e-mail: donbalogluokan@hotmail.com. \\ ORCID: 0000-0001-5401-4772 \\ *Sorumlu yazar/ Corresponding Author: Mehmet Okan Donbaloğlu \\ Gönderim Tarihi / Received: 06.04.2021 \\ Kabul Tarihi / Accepted: 20.09.2021 \\ DOI: $10.34087 /$ cbusbed.910797
}

\begin{abstract}
Giriş ve Amaç: Bu çalışma, siyanoakrilat embolizasyonunun etkinliğini değerlendirmeyi ve büyük safenöz ven yetmezliğini tedavi etmek için siyanoakrilat embolizasyon işlemlerinin kısa ve orta vadeli sonuçlarını analiz etmeyi amaçlamaktadir.

Gereç ve Yöntemler: Büyük safenöz venin ciddi yetersizliği nedeniyle siyanoakrilat embolizasyonu ile tedavi edilen 582 hasta çalışmaya dahil edildi ve geriye dönük olarak analiz edildi. Hastalar ameliyat sonrası birinci ay, altıncı ay, birinci yıl ve ikinci yılda klinik olarak değerlendirildi. Tedavi edilen uzuvlar ayrı ayrı değerlendirildi ve kaydedildi. Bulgular: Postoperatif dönemde reflü $2(\% 0.3)$ hastada 12. ayda $0.5 \mathrm{sn}, 24$. ayda $2(\% 0.3)$ hastada 1 sn düzeyinde değerlendirildi. Hastalar ağrı, yanma, yorgunluk, kaşıntı gibi minör komplikasyonların 12. ayda\% 98.8 oranında iyileştiğini belirtmişlerdir. Önemli bir komplikasyon olan derin ven trombozu, 12. ayda 1 (\% 0.2$)$ hastada görüldü. Preoperatif olarak belgelenen ortalama venöz klinik şiddet skoru $8.86 \pm 1.59$ 'dan $0.88 \pm 0.61$ 'e $(\mathrm{p}<0.05)$ ve ağrı skalası skoru $7.93 \pm 0.75$ 'ten $0.73 \pm 0.73$ 'e anlamlı olarak azald 1 ( $\mathrm{p}<0.05)$.

Sonuç: Yüksek oklüzyon oranları, çok az komplikasyon ve yüksek hasta konforu sağlamanın yanı sıra kozmetik sonuçlar açısından da başarılı bir uygulama olması nedeniyle büyük safen ven yetmezliğinin tedavisinde uygun endikasyonda güvenle kullanılabileceği düşünülmektedir.
\end{abstract}

Anahtar kelimeler: Büyük safenöz ven, Endovenöz tedavi, Siyanoakrilat embolizasyonu.

\footnotetext{
Abstract

Objective: The present study aimed to evaluate the efficacy of cyanoacrylate embolization and to analyze the shortto mid-term results of cyanoacrylate embolization procedures to treat great saphenous vein insufficiency.

Materials and Methods: 582 patients treated with cyanoacrylate embolization due to severe incompetence of the great saphenous vein were included in the study and analyzed retrospectively. Patients were evaluated clinically on the first month, sixth month, first year and second year after the operation. The treated limbs were evaluated and recorded separately.

Results: In the postoperative period, reflux was assessed at the level of $0.5 \mathrm{sec}$ in $2(0.3 \%)$ patients in the 12 th month, and $1 \mathrm{sec}$ in $2(0.3 \%)$ patients in the 24th month. The patients stated that minor complications such as pain, burning, fatigue, itching $98.8 \%$ healing in the 12 th month. Deep vein thrombosis, which is a major complication, was seen in $1(0.2 \%)$ patient at the 12 th month. Preoperatively documented mean venous clinical severity score from $8.86 \pm 1.59$ to $0.88 \pm 0.61(\mathrm{p}<0.05)$, and pain scale score significantly reduced from $7.93 \pm 0.75$ to $0.73 \pm 0.73(\mathrm{p}<0.05)$.

Conclusion: It is believed that it can be used safely in the appropriate indication for the treatment of great saphenous vein insufficiency as it is a successful application in terms of cosmetic results as well as providing high occlusion rates, very few complications, and high patient comfort.
} 
Keywords: Cyanoacrylate embolization, Endovenous therapy, Great saphenous vein.

\section{Introduction}

Chronic venous insufficiency (CVI) is expressed as a condition that includes subjective symptoms such as pain, cramping, itching, edema, the restlessness of the legs, skin changes that affect the venous system in the lower extremities and causes a significant decrease in the quality of life $[1,2]$. It is very common in society and occurs in $25 \%$ of women and $15 \%$ of men. It can appear as a cosmetic problem just like telangiectasia, and it can also cause serious skin changes in the form of an ulcer [3]. The main pathology that causes CVI is venous hypertension, which is called increased pressure due to the valve insufficiency or venous occlusion. Venous insufficiency that causes varicose veins is frequently seen in superficial veins and rarely in deep veins. Some of these patients may develop thrombophlebitis and related pulmonary embolism in varicose veins $[4,5]$. The main goal in treatment should be the elimination of reflux. Although open surgical methods such as ligation and stripping have been used as a standard treatment for many years, endovenous interventions such as radiofrequency ablation (RFA), laser ablation (EVLA) and cyanoacrylate embolization (CAE) have been widely used in recent years [6, 7]. Cyanoacrylate Embolization (CAE): CAEs are adhesives with one-component, solvent-free, fast drying (2-50 seconds), high heat resistance, adhesion with a small amount, penetrating even very small spaces. As soon as the air comes into contact with blood and tissues, the reaction is triggered and begins to polymerize. It forms a high-voltage resistant film in 6090 seconds $[8,9]$. On the other hand, no negative effects on prothrombin activity, fibrinogen, thrombocyte count, total and subgroup leukocyte counts have been reported. Hence, it does not have a hemolytic effect [810]. The use of CAE in the treatment of venous insufficiency is becoming more common today. This study aims to present the results in severe incompetence of the great saphenous vein that it was treated with $\mathrm{CAE}$ embolization method in a large patient population in the clinic.

\section{Materials ve Methods}

A total of 582 patients who were admitted to the Bitlis State Hospital Cardiovascular Surgery Clinic between January 2017 and February 2020 and were treated with the CAE method were included in the study. All patients were evaluated with the objectively accepted Clinical severity, Etiology, Anatomy, Pathophysiology (CEAP) score, Venous Clinical Severity Score (VCSS), and Visual Analogue Scale (VAS). All patients were evaluated preoperatively according to the CEAP classification. The questionnaire includes all clinical findings that may occur in patients with venous insufficiency and also shows numerical scoring after control. It also includes etiological, anatomical and pathophysiological controls and scoring $[11,12]$.
The patients were subjected to a Venous Clinical Severity Score (VCSS) questionnaire before the operation and during the postoperative period for the 1st and sixth month, first and 2 nd year and the data were recorded. ( 0 score does not show a significant venous disease, and 30 score is the most severe score) [13].

Visual Analogue Scale (VAS) was used to determine the severity of the patients' complaints. The patients were asked to mark the degree of their complaints on a 10-point Likert-type scale. According to the scale, the value of ' 0 ' showed that there were no complaints, while the value of '10' showed that their complaints were very severe. VAS scoring questionnaire was applied to all patients in the preoperative period and the postoperative 1st, 6th, 12th and 24th months.

Duplex ultrasound scan (DUS) results of the 6th, 12th and 24th months after the operation were compared. Total occlusion of the vein to which the procedure was applied was defined as the success of the operation. All patients at DUS had grade 4 reflux in the saphenofemoral junction (SFJ). The deep venous system was normal in all patients. The inclusion criteria were GSV reflux with $>0.5 \mathrm{~s}$. Symptomatic of the patient, deficiency in the only GSV and its branches. Patients with deep venous thrombosis, deep venous insufficiency, healed / active venous ulcer, immobility, incompetent anterior accessory GSV, small saphenous vein, pregnant and breastfeeding patients, lymphedema, and patients with peripheral artery disease were excluded from the study. No patients were treated consecutively on both lower extremities. While conditions that can heal with simple medical intervention such as pain, induration, ecchymosis, paresthesia, superficial thrombophlebitis, and temporary color change on the skin are considered minor complications, the conditions such as motor nerve damage, major artery and vein injury, skin burn, arteriovenous fistula formation, DVT, and pulmonary thromboembolism requiring close medical monitoring were evaluated as major complications.

\subsection{Technique}

Cyanoacrylate Embolization (CAE) Procedure: All patients who received cyanoacrylate embolization agent were treated in the cardiovascular surgery operating room. DUS guided puncture was performed under local anesthesia with a seldinger technique to GSV from a suitable area at the knee level, and a 7F sheath was placed. Embolizing agent system was used in all patients. The catheter of the system was taken forward approximately $2.5-3 \mathrm{~cm}$ distal to the SFJ. The patient was placed in the trendelenburg position, and the SFJ was collated by pressing with the usg probe. Within approximately 30 seconds, CAE was injected continuously throughout the saphena vein traction, and external compression was applied simultaneously. Compressions were terminated 3 minutes after the injection was finished. Then, the reduction in vein diameter and echogenicity increment in the vein wall 
was controlled with DUS. Miniphlebectomies (MP's) were performed on secondary varicose tributaries. Compression pads were applied over the course of the treated vein, and an elastic compression bandage was placed on the treated limb for the first $24 \mathrm{~h}$ after the operation. Patients then wore full-thigh compression stockings $(20-30 \mathrm{~mm} \mathrm{Hg})$ for a month. All patients were instructed to ambulate immediately on the day of procedure, advised to walk regularly during the recovery period. The process lasted $14.60 \pm 3.33$ minute to this point. $574(98.6 \%)$ patients were discharged on the same day, and $8(1.4 \%)$ patients were discharged 24 hours later.

Follow-up examinations

The patients were evaluated clinically in the postoperative first month, sixth month, first year and second year. DUS was performed in the sixth month, first year, and second year to examine venous reflux in the treated segment of GSV. VCSS and CEAP scores of the patients were also recorded at each visit. Pain was measured using the Visual Analogue Scale (VAS). All patients were asked to use the VAS and fill out the given cards at the time of discharge. Cards were taken from the patients in the first month control. CVI symptoms, minor and major complaints were recorded as complications.

\section{Statistical analysis}

Descriptive statistical methods such as mean, standard deviation and percentage were used to evaluate the demographic and clinical features of the patients. In order to evaluate the change in the mean of VAS, CEAP and VCSS, ANOVA analysis was used for repeated measures, and Bonferroni Test was used to compare the change between measurements. Logistic Regression Analysis was used to examine the factors that are effective in increasing or decreasing the risk associated with VAS, CEAP and VCSS symptoms that persist after two years. The significance level was determined as $\mathrm{p}<0.05$ for all analyzes. IBM SPSS 22.0 program was used in the implementation of the analyzes.

\section{Results and Discussion}

\subsection{Results}

The average age of 582 participants evaluated in the study was $45.44 \pm 12.27(\mathrm{Min}=18, \mathrm{Max}=81)$ and 305 of the patients $(52.4 \%)$ were male. Average height of all participants was $165.17 \pm 7.31 \mathrm{~cm}(\mathrm{Min}=149$, Max $=183)$, USGG1 mean was $7.79 \pm 1.92(\operatorname{Min}=5$, Max $=14)$ and duration of the operation was $14.60 \pm 3.33$ minutes $(\operatorname{Min}=10$, Max $=30)$. Diabetes Mellitus $(\mathrm{DM})$ was found in $56(9.6 \%)$ of participants, hypertension (HT) was found in $101(17.4 \%)$ of them, and Coronary Artery Disease (CAD) was detected in 35 (6.0\%) of patients. In addition, it was stated that there were 293 (50.3\%) smokers and $292(50.2 \%)$ patients who had the family history about the insufficiency. $554(95.2 \%)$ of the patients were evaluated by GSV, $28(4.8 \%)$ of them were evaluated both GSV and pake extraction. Local anesthesia for $564(95.2 \%)$ patients and spinal anesthesia for $18(3.1 \%)$ patients were applied. In addition, $574(98.6 \%)$ of the patients were discharged within 24 hours after the operation. The other $8(1.4 \%)$ patients were discharged after 24 hours (Table 1).

In the preoperative period, $140(24.1 \%)$ of the patients were found to have fatigue in the leg, 186 (32.0\%) of them had pruritus, and $173(29.7 \%)$ of them had burned. In the first postoperative month, 18 (3.1\%) of the patients had leg fatigue, $21(3.6 \%)$ of them had pruritus, and $55(9.5 \%)$ of them had burned. In the sixth month postoperative period, it was evaluated that 2 $(0.3 \%)$ of the patients had leg fatigue, $5(0.9 \%)$ of them had pruritus and $10(1.7 \%)$ of them had burned. Pruritus in only $2(0.3 \%)$ patients and burning sensation in 5 (0.9) patients were evaluated at the postoperative 12th month. In addition, 22 patients $(3.8 \%)$ in the 1 st postoperative month, and two patients $(0.3 \%)$ in the 6 th month (postoperative) were found to have redness which disappeared at the end of 12th month. In the first postoperative month, $8(1.4 \%)$ patients had thrombophlebitis. In the sixth month postoperative period, thrombophlebitis in $2(0.2 \%)$ patients were detected. In the twelfth month postoperative stage 1 $(0.2 \%)$ patient had DVT (Table 2 ).

Reflux was found that 1.5 seconds in $2(\% 0,3)$ patients, 2 seconds in $2(\% 0,3)$ patients, 3 seconds in $25(\% 4,3)$ patients, 4 seconds in $220(\% 37,8)$ patients and more than 4 seconds in $333(\% 57,2)$ patients in the preoperative stage. In the postoperative period, reflux was assessed at the level of $0.5 \mathrm{sec}$ in $4(0.7 \%)$ patients in the 6th month, $0.5 \mathrm{sec}$ in $2(0.3 \%)$ patients in the 12 th month, and $1 \mathrm{sec}$ in $2(0.3 \%)$ patients in the 24th month. In addition, in the preop period, grade 2 reflux in 7 $(1.2 \%)$ patients, grade 3 reflux in $59(10.1 \%)$ patients and grade 4 reflux in $516(88.7 \%)$ patients were detected. It was found that there were grade 1 reflux in $4(0.7 \%)$ patients and grade 2 reflux in $1(0.2 \%)$ patient in the 6 th month of the postoperative period. In the 12 th month of the postop, $2(0.3 \%)$ patients had grade 1 and $1(0.2 \%)$ patient had grade 2 reflux. Only grade 1 reflux was found in $3(0.5 \%)$ patients at the postoperative 24 th month (Table 3 ).

In the preop period, the mean VAS of patients was 7.93 $\pm 0.75(\mathrm{LL}=7.87, \mathrm{UL}=7.99), \mathrm{CEAP}$ mean was $3.92 \pm$ $0.52(\mathrm{LL}=3.88, \mathrm{UL}=3.96)$ and VCSS the mean was $8.86 \pm 1.59(\mathrm{LL}=8.73, \mathrm{UL}=8.99)$. According to ANOVA analysis for repeated measures, there was a statistically significant change in the mean of the VAS ( $p<0.001)$, CEAP $(\mathrm{p}<0.001)$ and the VCSS $(\mathrm{P}<0.001)$ between the preop and the postop (1st, 6th, 12th, 24th months of the postop period) measurements. According to the Bonferroni test, although the mean of the VAS was statistically significant from the preop period to the 1 st month of the postop period $(\mathrm{p}<0.001)$ and from the 1 st month to the 6th month $(\mathrm{p}<0.001)$ in the postoperative period, it was found that the mean of the VAS from the sixth month to 12th month and the mean of the VAS from 12th month to 24th month during the postoperative period did not show any statistically significant change. CEAP scores showed statistically significant change from the preop period to 1 st month 
Tablo 1. Demographic and clinical features of the participants.

\begin{tabular}{|c|c|c|c|}
\hline & n & Ort. \pm Ss. & Minimum-Maksimum \\
\hline Age & 582 & $45,44 \pm 12,27$ & $18-81$ \\
\hline Boy & 582 & $165,17 \pm 7,31$ & $149-183$ \\
\hline $\begin{array}{l}\text { Diameter (mm) of GSV at } \\
\text { SFJ }\end{array}$ & 582 & $7,79 \pm 1,92$ & $5-14$ \\
\hline $\begin{array}{l}\text { Length }(\mathrm{cm}) \text { of treated } \\
\text { GSV }\end{array}$ & 582 & 32.985 .67 & $26-42$ \\
\hline \multirow[t]{2}{*}{ Operation time } & 582 & $14,60 \pm 3,33$ & $10-30$ \\
\hline & & $\mathrm{n}$ & $\%$ \\
\hline \multirow[t]{2}{*}{ Gender } & Woman & 277 & 47.6 \\
\hline & Man & 305 & 52.4 \\
\hline \multirow[t]{2}{*}{ Diabetes mellitus } & No & 526 & 90.4 \\
\hline & Yes & 56 & 9.6 \\
\hline \multirow{2}{*}{ Hypertension } & No & 481 & 82.6 \\
\hline & Yes & 101 & 17.4 \\
\hline \multirow[t]{2}{*}{ Coronary artery disease } & No & 547 & 94.0 \\
\hline & Yes & 35 & 6.0 \\
\hline \multirow[t]{2}{*}{ Smoking } & No & 289 & 49.7 \\
\hline & Yes & 293 & 50.3 \\
\hline \multirow[t]{2}{*}{$\begin{array}{l}\text { Venous insufficiency in the } \\
\text { family }\end{array}$} & No & 290 & 49.8 \\
\hline & Yes & 292 & 50.2 \\
\hline \multirow[t]{2}{*}{ Sides of extremities } & Right & 331 & 56.9 \\
\hline & Left & 251 & 43.1 \\
\hline \multirow[t]{2}{*}{ GSV } & Great saphenous vein & 554 & 95.2 \\
\hline & $\begin{array}{c}\text { Great saphenous vein + Pake } \\
\text { extraction }\end{array}$ & 28 & 4.8 \\
\hline \multirow[t]{2}{*}{ Operation method } & Local anesthesia & 564 & 96.9 \\
\hline & Spinal anesthesia & 18 & 3.1 \\
\hline \multirow[t]{2}{*}{ Discharged } & $\leq 24$ hours & 574 & 98.6 \\
\hline & $>24$ hours & 8 & 1.4 \\
\hline
\end{tabular}

Table 2. Changes of the venous insufficiency symptom rates of the participants for 12 months

\begin{tabular}{|l|l|c|c|c|c|}
\hline Complications & Symptoms & $\begin{array}{c}\text { Preop } \\
\mathbf{n}(\boldsymbol{\%})\end{array}$ & $\begin{array}{c}\text { Postop 1 } \\
\text { month } \\
\mathbf{n}(\boldsymbol{\%})\end{array}$ & $\begin{array}{c}\text { Postop 6 } \\
\text { month } \\
\mathbf{n}(\boldsymbol{\%})\end{array}$ & $\begin{array}{c}\text { Postop 12 }^{\text {th }} \\
\text { month } \\
\text { n }(\boldsymbol{\%})\end{array}$ \\
\hline Minör & Fatigue in leg & $140(24.1)$ & $18(3.1)$ & $2(0.3)$ & $0(0.0)$ \\
\hline Minör & Pruritus in leg & $186(32.0)$ & $21(3.6)$ & $5(0.9)$ & $2(0.3)$ \\
\hline Minör & Burning in leg & $173(29.7)$ & $55(9.5)$ & $10(1.7)$ & $5(0.9)$ \\
\hline Minör & Redness in leg & - & $22(3.8)$ & $2(0.3)$ & $0(0.0)$ \\
\hline Minör & Thrombophlebitis & - & $8(1.4)$ & $2(0.3)$ & $0(0.0)$ \\
\hline Major & $\begin{array}{l}\text { Deep venous } \\
\text { trombosis }\end{array}$ & - & - & - & $1(0.2)$ \\
\hline Major & $\begin{array}{l}\text { Pulmoner } \\
\text { Embolism }\end{array}$ & - & - & - & - \\
\hline
\end{tabular}

of the postop ( $\mathrm{p}<0.001$ ), from 1 st month to 6th month during the postoperative period $(\mathrm{p}<0.001)$, from 6 th month to 12 th month in the postoperative stage ( $p$ $<0.001)$. However; it was found that the decrease in the CEAP scores was not statistically significant from 12 th to 24th month during the postop stage. It was found that the VCSS scores decreased significantly from the preop period to 1 st month in the postop stage ( $p<0.001)$, from 1 st month to 6th month of the postop ( $p<0.001$ ), from 6th month to 12th month in the postop period (p
$<0.001)$ and from 12 th month to 24th month during the postoperative stage ( $\mathrm{p}<0.001)$ (Table 4).

According to the VAS $(>0)$ at least one symptom in $333(57.2 \%)$ patients, according to the CEAP $(>0)$ at least one symptom in $157(27.0 \%)$ patients and according to the VCSS (>0) at least in $442(75.0 \%)$ patients was found as a symptom. According to the presence and absence of the VAS, CEAP, and VCSS symptoms, three different Logistic Regression Analysis were applied. As a result, it was found that age was a 
Table 3. Changes of the reflux and grade of reflux rates of the participants for 24 months.

\begin{tabular}{|c|c|c|c|c|c|}
\hline & & Preoperative & $\begin{array}{c}\text { Postoperative }^{\text {th }} \\
\text { month } \\
\text { n }(\%)\end{array}$ & $\begin{array}{c}\text { Postoperative } \\
12^{\text {th }} \text { month } \\
\text { n }(\%)\end{array}$ & $\begin{array}{c}\text { Postoperative } \\
2^{\text {th }} \text { month } \\
\text { n }(\%) \\
\end{array}$ \\
\hline \multirow[t]{8}{*}{ Reflux } & No & $0(0.0)$ & $578(99.3)$ & $580(99.7)$ & $580(99.7)$ \\
\hline & $0.5 \mathrm{sec}$ & $0(0.0)$ & $4(0.7)$ & $2(0.3)$ & $0(0.0)$ \\
\hline & $1 \mathrm{sec}$ & $0(0.0)$ & $0(0.0)$ & $0(0.0)$ & $2(0.3)$ \\
\hline & $1.5 \mathrm{sec}$ & $2(0.3)$ & $0(0.0)$ & $0(0.0)$ & $0(0.0)$ \\
\hline & $2 \mathrm{sec}$ & $2(0.3)$ & $0(0.0)$ & $0(0.0)$ & $0(0.0)$ \\
\hline & $3 \mathrm{sec}$ & $25(4.3)$ & $0(0.0)$ & $0(0.0)$ & $0(0.0)$ \\
\hline & $4 \mathrm{sec}$ & $220(37.8)$ & $0(0.0)$ & $0(0.0)$ & $0(0.0)$ \\
\hline & $>4 \mathrm{sec}$ & $333(57.2)$ & $0(0.0)$ & $0(0.0)$ & $0(0.0)$ \\
\hline \multirow[t]{5}{*}{ Grade of reflux } & 0 & $0(0.0)$ & $577(99.1)$ & $579(99.5)$ & $579(99.5)$ \\
\hline & 1 & $0(0.0)$ & $4(0.7)$ & $2(0.3)$ & $3(0.5)$ \\
\hline & 2 & $7(1.2)$ & $1(0.2)$ & $1(0.2)$ & $0(0.0)$ \\
\hline & 3 & $59(10.1)$ & $0(0.0)$ & $0(0.0)$ & $0(0.0)$ \\
\hline & 4 & $516(88.7)$ & $0(0.0)$ & $0(0.0)$ & $0(0.0)$ \\
\hline
\end{tabular}

Tablo 4. Change of Pain Scales Scores, CEAP and VCSS values for 24 months

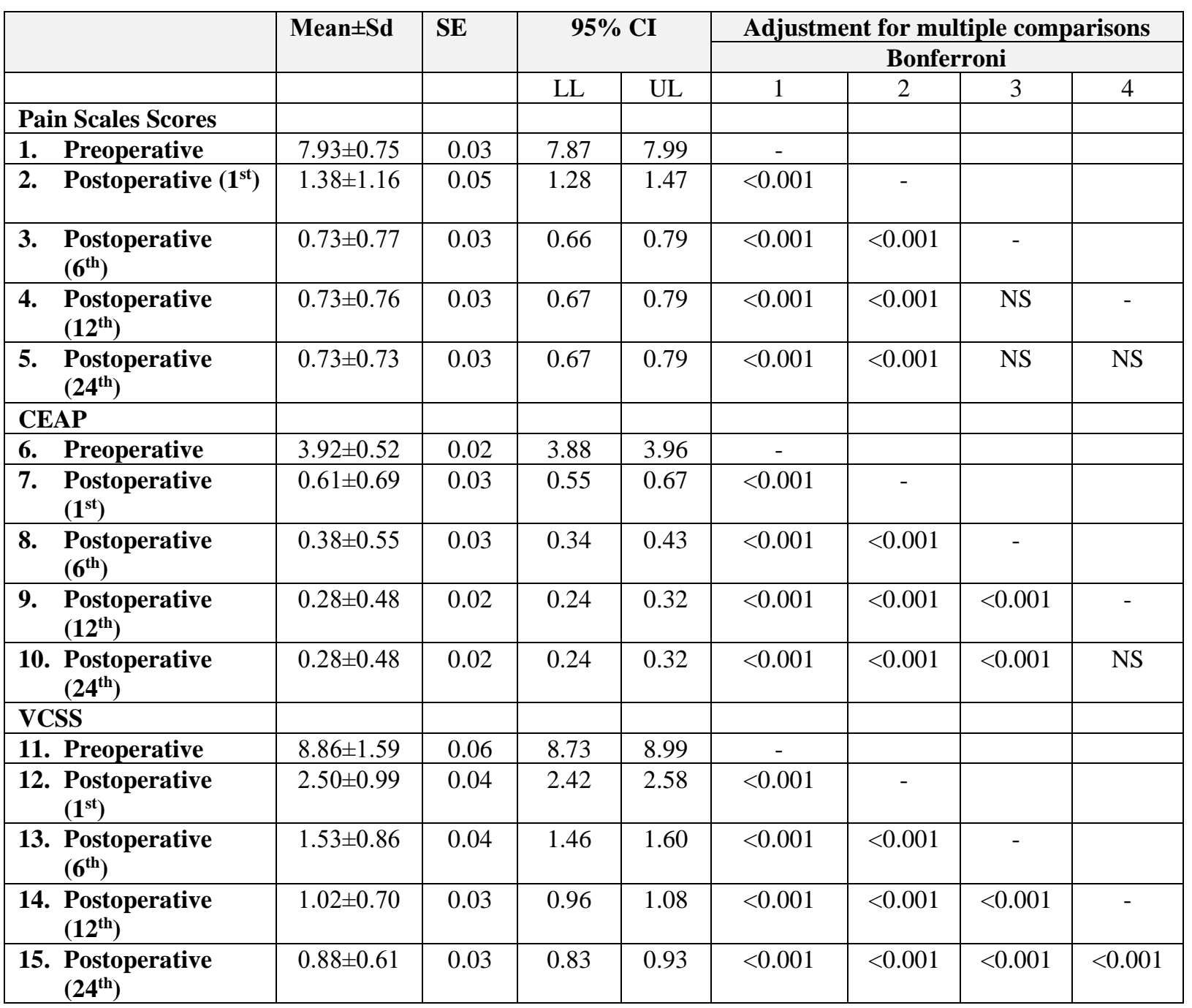

$\mathrm{Sd}=$ Standard deviation, NS=Not Significant, One-way repeated measures ANOVA and Bonferroni test results 
statistically significant variable (odds ratio $=1.02, \mathrm{LL}$ $=1.00, \mathrm{UL}=1.04 ; \mathrm{p}=0.030$ ) in increasing the risk of being the VAS. In increasing the risk of presence of the CEAP, family history (odds ratio $=1.70, \mathrm{LL}=1.16, \mathrm{UL}$ $=2.50 ; \mathrm{p}=0.007$ ) and operation time (odds ratio $=1.07$, $\mathrm{LL}=1.01, \mathrm{UL}=1,14 ; \mathrm{p}=0.017$ ) were found as statistically significant factors. In addition, it was found that local operation type (odds ratio $=0.28, L L=0.10$, $\mathrm{UL}=0.77 ; \mathrm{p}=0.014$ ) was a statistically significant factor in reducing the risk of presence of the CEAP. Male gender (odds ratio $=0.63, \mathrm{LL}=0.42, \mathrm{UL}=0.95$; $\mathrm{p}=0.014$ ) was found to be a statistically significant factor in reducing the risk of the VSCC presence (Table $5)$.

Tablo 5. Logistic Regression Analysis according to the presence of AS, CEAP and VCSS at the end of 24 months

\begin{tabular}{|c|c|c|c|c|c|c|c|c|}
\hline \multirow[b]{2}{*}{ Model 1 (VAS) } & \multirow[t]{2}{*}{ B } & \multirow[t]{2}{*}{ S.E. } & \multirow[t]{2}{*}{ Wald } & \multirow[t]{2}{*}{ df } & \multirow[t]{2}{*}{$\mathbf{p}$} & \multirow[t]{2}{*}{ Odds ratio } & \multicolumn{2}{|c|}{$\begin{array}{l}\text { 95\% C.I.for } \\
\text { EXP(B) }\end{array}$} \\
\hline & & & & & & & LL & $\mathrm{UL}$ \\
\hline Age & 0.01 & 0.01 & 4.72 & 1 & $\mathbf{0 . 0 3 0}$ & 1.02 & 1.00 & 1.04 \\
\hline Gender (Man) & -0.05 & 0.18 & 0.08 & 1 & 0.771 & 0.94 & 0.67 & 1.35 \\
\hline BOY & 0.01 & 0.01 & 0.16 & 1 & 0.687 & 1.01 & 0.98 & 1.03 \\
\hline Diabetes mellitus (Yes) & 0.33 & 0.34 & 0.94 & 1 & 0.332 & 1.39 & 0.72 & 2.69 \\
\hline Hypertension (Yes) & 0.10 & 0.27 & 0.14 & 1 & 0.706 & 1.11 & 0.66 & 1.88 \\
\hline Coronary artery disease (Yes) & 0.16 & 0.45 & 0.12 & 1 & 0.729 & 1.17 & 0.48 & 2.83 \\
\hline Smoking (Yes) & -0.01 & 0.17 & 0.01 & 1 & 0.935 & 0.99 & 0.70 & 1.38 \\
\hline Venous insufficiency in the family (Yes) & 0.06 & 0.17 & 0.11 & 1 & 0.746 & 1.06 & 0.76 & 1.48 \\
\hline Sides of extremities (Right) & -0.08 & 0.17 & 0.22 & 1 & 0.641 & 0.92 & 0.66 & 1.30 \\
\hline Operation time & -0.00 & 0.03 & 0.01 & 1 & 0.912 & 1.00 & 0.95 & 1.05 \\
\hline Operation method (Local) & -1.07 & 0.59 & 3.34 & 1 & 0.067 & 0.34 & 0.11 & 1.08 \\
\hline GSV (Only great saphenous vein) & 0.24 & 0.41 & 0.35 & 1 & 0.553 & 1.27 & 0.56 & 2.81 \\
\hline \multicolumn{9}{|l|}{ Model 2 (CEAP) } \\
\hline Age & -0.02 & 0.01 & 3.46 & 1 & 0.063 & 0.98 & 0.97 & 1.00 \\
\hline Gender (Man) & 0.37 & 0.20 & 3.28 & 1 & 0.070 & 1.45 & 0.97 & 2.16 \\
\hline BOY & -0.01 & 0.01 & 0.07 & 1 & 0.789 & 1.00 & 0.97 & 1.02 \\
\hline Diabetes mellitus (Yes) & -0.15 & 0.39 & 0.15 & 1 & 0.697 & 0.86 & 0.40 & 1.85 \\
\hline Hypertension (Yes) & -0.26 & 0.31 & 0.67 & 1 & 0.415 & 0.77 & 0.42 & 1.43 \\
\hline Coronary artery disease (Yes) & -0.35 & 0.50 & 0.48 & 1 & 0.488 & 0.71 & 0.26 & 1.89 \\
\hline Smoking (Yes) & -0.08 & 0.20 & 0.15 & 1 & 0.702 & 0.93 & 0.63 & 1.36 \\
\hline Venous insufficiency in the family (Yes) & 0.53 & 0.20 & 7.35 & 1 & 0.007 & 1.70 & 1.16 & 2.50 \\
\hline Sides of extremities (Right) & -0.18 & 0.20 & 0.79 & 1 & 0.373 & 0.84 & 0.57 & 1.23 \\
\hline Operation time & 0.07 & 0.03 & 5.73 & 1 & 0.017 & 1.07 & 1.01 & 1.14 \\
\hline Operation method (Local) & -1.27 & 0.52 & 6.05 & 1 & 0.014 & 0.28 & 0.10 & 0.77 \\
\hline GSV (Only great saphenous vein) & -0.46 & 0.43 & 1.16 & 1 & 0.281 & 0.63 & 0.28 & 1.45 \\
\hline \multicolumn{9}{|l|}{ Model 3 (VSCC) } \\
\hline Age & -0.01 & 0.01 & 1.94 & 1 & 0.163 & 0.98 & 0.97 & 1.01 \\
\hline Gender (Man) & -0.46 & 0.21 & 4.82 & 1 & 0.028 & 0.63 & 0.42 & 0.95 \\
\hline BOY & -0.02 & 0.02 & 2.12 & 1 & 0.146 & 0.98 & 0.95 & 1.01 \\
\hline Diabetes mellitus (Yes) & 0.18 & 0.38 & 0.21 & 1 & 0.649 & 1.19 & 0.56 & 2.52 \\
\hline Hypertension (Yes) & -0.01 & 0.31 & 0.00 & 1 & 0.988 & 1.00 & 0.55 & 1.82 \\
\hline Coronary artery disease (Yes) & -0.53 & 0.54 & 0.95 & 1 & 0.330 & 0.59 & 0.20 & 1.71 \\
\hline Smoking (Yes) & 0.06 & 0.20 & 0.09 & 1 & 0.765 & 1.06 & 0.72 & 1.57 \\
\hline Venous insufficiency in the family (Yes) & -0.03 & 0.20 & 0.03 & 1 & 0.870 & 0.97 & 0.66 & 1.43 \\
\hline Sides of extremities (Right) & -0.20 & 0.20 & 0.99 & 1 & 0.321 & 0.82 & 0.55 & 1.22 \\
\hline Operation time & 0.01 & 0.03 & 0.05 & 1 & 0.830 & 1.01 & 0.95 & 1.07 \\
\hline Operation method (Local) & -0.30 & 0.60 & 0.25 & 1 & 0.618 & 0.74 & 0.23 & 2.39 \\
\hline GSV (Only great saphenous vein) & 0.19 & 0.45 & 0.19 & 1 & 0.666 & 1.21 & 0.51 & 2.90 \\
\hline
\end{tabular}

Model 1: VAS yes (1), X2 (12, N=582)=9.86, $\mathrm{p}=0.628$ Nagelkerke R kare=0.02, Overall Percentage $=57.6$. Model 2: CEAP yes (1), X2 (12, N=582)=37.19, p<0.001, Nagelkerke R kare=0.06, Overall Percentage=73.2. Model 3: VCSS yes (1), X2(12, N=582)=11.64, p=0.475, Nagelkerke R kare=0.02, Overall Percentage=75.9. 


\section{Discussion}

Minimally invasive methods such as sclerotherapy, EVLA, RFA and CAE have come to the fore in the treatment of saphenous vein insufficiencies. These methods, performed under DUS guidance and local anesthesia, have replaced surgical treatments [14]. In a meta-analysis published by Van Den Bos et al., 64 studies were performed in a total of 12.320 patients, and they found success rates at the end of 3 years as $78 \%$ in striping patients, $77 \%$ in foam sclerotherapy, $84 \%$ in RFA patients, and $94 \%$ in EVLA patients. [16]. In addition to the high success rates of minimally invasive methods, they have become particularly preferred treatment methods for reasons such as ease of application, fewer complication rates, faster mobilization, shorter hospitalization duration, and less pain $[15,16]$. In the study, local anesthesia was applied to $564(95.2 \%)$ patients, and spinal anesthesia was applied to $18(3.1 \%)$ patients. In addition, $574(98.6 \%)$ of the patients were discharged within 24 hours after the operation. The other $8(1.4 \%)$ patients were discharged after 24 hours. While patients who underwent local anesthesia were mobilized after an average of 1 hour, patients who underwent spinal anesthesia were mobilized after an average of 6 hours. The short and medium- term complication rate was below $1 \%$, and the transaction success was $99 \%$, which were consistent with the literature.

Although CAE has been used as an intravascular embolizing agent for nearly 30 years, its usage in the treatment of venous insufficiency is relatively new compared to other minimally invasive treatments. In recent years, articles related to the use of CAE in this direction have started to take its place in the literature, and it has been found to be a highly effective treatment option by providing occlusion between 92-99\% [16, 17]. In a randomized study comparing RFA and CAE, CAE showed that it is as effective as RFA and was reliable in the treatment of GSV with a deficiency in 3 months [18]. In the study, all 582 patients had 100\% postoperative occlusion. At the same time, their controls with DUS showed minimal (1 second) recanalization and mild reflux in only $4(\% 0,7)$ patients at 6 th month, $2(\% 0,3)$ patients at 12 th month, and 2 $(\% 0,3)$ patients at 24 th month during the postop period. The success rate was around $99 \%$, and it was compatible with the literature. In minimally invasive treatment methods based on the thermal ablation, such as RFA and EVLA, the use of tumescent anesthesia (TA) is required. In addition, tumescent anesthesia is a difficult and time-consuming procedure [19]. TA protects perivascular tissues and skin from high temperature by forming a protective layer around the vein [16]. However, skin burns can occur due to high energy application and exposure of insufficient tumescent anesthesia. In large series studies, skin burns were not reported, whereas in smaller studies several cases of superficial skin burns were reported [20, 22]. There is no need for TA in CAE treatment [23]. Since
TA was not used in the patients in the study, any complications related to TA did not occur.

In the studies conducted in the literature, it is observed that complications are less in minimally invasive methods. The duration of hospitalization is shorter and faster mobilization is provided $[15,16]$. In the study performed by Ovali on 205 patients by applying CAE, ecchymosis occurred in 21 patients (10\%), and tenderness is observed in 24 patients (12\%) [24]. Complications such as phlebitis and cellulite, which can be seen as more important, are at the level of $1 \%$. Major complications, such as deep venous thrombosis and pulmonary embolism, do not occur. In the study, redness in $22(3.8 \%)$ patients and thrombophlebitis in 8 $(1.4 \%)$ patients were detected in the first postoperative month, redness in $2(0.3 \%)$ patients and thrombophlebitis in $2(0.2 \%)$ patients were observed in the 6th month of the postoperative period, and those symptoms in patients disappeared after 12 th month. As a major complication, DVT was below $1 \%$ in the short and medium term. Medical treatment of the patients was started, and chronic DVT was observed in 1 patient during long-term follow-up, and follow-ups were done regularly.

\section{Conclusion}

In the current study, the mean operation duration was $14.60 \pm 3.33 \mathrm{~min}$, while the mean hospitalization duration was on the same day in 574 patients (98.6\%), and was 24 hours later in 8 patients $(1.4 \%)$ who underwent spinal anesthesia. Thus, early mobilization was provided, and the patient's comfort was increased, and the cost was reduced. In the 6th month, 1st year and 2nd year DUS examination, the occlusion rates were around $99 \%$, and the reflux rates were below $1 \%$ in the study, and it objectively demonstrates the effectiveness of CAE. On the other hand, Senol et al. [25] found the 3 -month closure rate to be $97.6 \%$ in a similar study. The change of symptoms in patients after the treatment is evaluated subjectively. Although it is reported a singlecenter data with a large patient population on incompetence of the great saphenous vein, this study has various limitations. The most important limitations of this study are the retrospective analysis and a short follow-up period. Only incompetence of the great saphenous vein closure is focused. Although pake extraction was performed in some procedures, the disappearance of varicose veins and recurrence of varicose veins has not been analyzed. Overall treatment costs, including treatment costs and costs related to return-to-work, have not been analyzed. In conclusion, CAE provides high occlusion in the treatment of saphenous vein deficiencies, very few complications and high patient comfort, and a high chance of success. These results should be supported by long-term results and studies in larger patient groups.

\section{References}

1. Gulati, O.P, Pycnogenol, A nutraceutical for venous health, Biomedical Review, 2008, 19, 33-43.

2.Bergan, J.J, Schmid-Schönbein, G.W, Smith, P.D, et al., Chronic 
venous disease. The New England Jornal of Medicine 2006 , 355(5), 488-98

3. Callam, M.J, Epidemiology of varicose veins, British Journal of Surgery, 1994, 81, 167-73.

4. Decousus, H, Epinat, M, Guillot, K, et al., Superficial vein thrombosis: risk factors, diagnosis, and treatment, Current Opinion in Pulmonary Medicine, 2003, 393-397.

5. Verlato, F, Zucchetta, P, Prandoni, P, et al., An unexpectedly high rate of pulmonary embolism in patients with superficial thrombophlebitis of the thigh, Journal of Vascular Surgery, 1999 30, 1113-1115.

6. Puggioni, A, Kalra, M, Carmo, M, et al., Endovenous laser therapy and radiofrequency ablation of the great saphenous vein: analysis of early efficacy and complications, Journal of Vascular Surgery, 2005, 42, 488- 93.

7. Santler, B, Goerge, T, Chronic venous insufficiency - a review of pathophysiology, diagnosis, and treatment, Journal der Deutschen Dermatologischen Gesellschaft, 2017, 15, 538-56.

8. Montanaro, L, Arciola, C.R, Cenni, E, et al., Cytotoxicity, blood compatibility and antimicrobial activity of two cyanoacrylate glues for surgical use, Biomaterials, 2001, 22, 59-66.

9.Pursifulla, N.F, Moreyb, A.F, Tissue glues and nonsuturing techniques, Current Opinion in Urology, 2007, 17, 396-401.

10. Pascual, G, Sotomayor, S, Rodríguez, M, et al., Cytotoxicity of cyanoacrylate-based tissue adhesives and short-term preclinical in vivo biocompatibility in abdominal hernia repair, PLoS One, 2016 , 11, e0157920.

11. Padberg, F.T Jr, CEAP classification for chronic venous disease, Disease-a-Month, 2005, 51, 176-82.

12. Gloviczki, P, Yao, J.S.T, (ed), Handbook of venous disorders,2nd edition, Arnold publishers. 2001

13. Garratt, A.M, Macdonald, L.M, Ruta, D.A, et al., Towards measurement of outcome for patients with varicose veins, Qual Health Care, 1993, 2, 5e10.

14. Brown, K, Moore, C.J, Update on the Treatment of Saphenous Reflux: Laser, RFA, or Foam?, Perspectives Vascular Surgery and Endovascular Therapy, 2009, December, 16.

15. Van den Bos, R, Arends, L, Kockaert, M, et al., Endovenous therapies of lower extremity varicosities: a meta-analysis, Journal of Vascular Surgery 2009, 49, 230.

16. Carroll, C, Hummel, S, Leaviss, J, et al., Systematic review, network metaanalysis and exploratory cost-effectiveness model of randomized trials of minimally invasive techniques versus surgery for varicose veins, British Jornal of Surgery, 2014, 101, 1040-52.

17. Uncu, H, Ocak, F.T, Karaca, S, et al., Variköz ven cerrahisinde 980 $\mathrm{nm}$ dalga boyu endovenöz lazer ablasyon ve radyofrekans ablasyonun orta dönem sonuçlarının karşılaştırılması, Türk Gögüs Kalp Damar Cerrahisi Dergisi, 2015, 23, 678-82.

18. Morrison, N, Gibson, K, McEnroe, S, et al., Randomized trial comparing cyanoacrylate embolisation and radiofrequency ablation for incompetent great saphenous veins (VeClose), Journal of Vascular Surgery, 2015, 61, 985-94.

19. Bozkurt, A.K, Yilmaz, M.F, A prospective comparison of a new cyanoacrylate glue and laser ablation for the treatment of venous insufficiency, Phlebology, 2016, 31(1 Suppl), 106-113.

20. Agus, G.B, Mancinı, S, Mag1, G, et al., The first 1000 cases of Italian Endovenous-laser Working Group (IEWG), Rationale, and long-term outcomes for the 1999-2003 period, International Angiology, 2006, 25, 209-215.

21. Ravi R, Rodriguez-Lopez JA, et al., Endovenous ablation of incompetent saphenous veins: a large single-center experience, Journal of Endovascular Therapy, 2006, 13, 244-248.

22. Sharıf, M.A, Soong, C.V, Lau, L.L, et al., Endovenous laser treatment for long saphenous vein incompetence, British Journal of Surgery, 2006, 93, 831-835.

23. Calık, E.S, Arslan, Ü, Ayaz, F, et al., N-butyl cyanoacrylate in the treatment of venous insufficiency--the effect of embolisation with ablative polymerisation, Vasa European Jornal of Vascular Medicine, 2016, 45, 241-6.

24. Oval1, C, Treatment of saphenous vein insufficiency with n-buty cyanoacrylate embolization: one center experience, Cukurova Medical Journal, 2018, 43(4), 886-891.

25. Şenol, S, Türker, F.S, Temiztürk, Z, Azboy, D, Endovenous ablation technique using N-butyl cyanoacrylate in varicose veins, Damar Cerrahisi Dergisi, 2018, 27, 61-64. http://edergi.cbu.edu.tr/ojs/index.php/cbusbed isimli yazarın CBU-SBED başlıklı eseri bu Creative Commons Alıntı-Gayriticari4.0 Uluslararası Lisansı ile lisanslanmıştır.

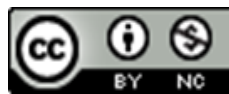

